\title{
GERAKAN KOMUNITAS PEREMPUAN "SRIKANDI LINTAS IMAN" YOGYAKARTA DALAM TELAAH PENDIDIKAN ISLAM MULTIKULTURAL
}

\section{Fatihaturrohmah}

Institut Ilmu Al Qur'an An Nur Yogyakarta rahmaelfatth30@gmail.com

Ahmad Shofiyuddin Ichsan Institut Ilmu Al Qur'an An Nur Yogyakarta ahmad.shofiyuddin.ichsan@gmail.com

\begin{abstract}
This study aims to determine the activities of women's community "Srikandi Lintas Iman" Yogyakarta in muticultural Islamic education study, to know the implications of multicultural Islamic education in the women's community in managing religious diversity in Yogyakarta, and to find out the supporting factors in the movement process in women's community "Srikandi Lintas Iman". This type of research is field research with a phenomenological approach. Data sources obtained through structured interviews, passive participant observation and documentation. Then, data analysis uses data analysis according to Cresswell. The results obtained that the women's community movement "Srikandi Lintas Iman" focused on several activities, namely cross-faith discussions, interfaith pilgrimages, and conflict resolution training. The implication is that their members are able to apply the values of multicultural Islamic education, namely inclusive, tolerance, pluralism, justice, and peace. To understand the supporting factors of this women's community, they are solid in carrying out their vision and mission together, leader continues to be active in directing, members come from various backgrounds, and the family system between members is still maintained.
\end{abstract}

Keywords: Women's Community, Multicultural Islamic Education 


\section{PENDAHULUAN}

Indonesia merupakan negara yang sangat plural dan beragam, di dalamnya terdapat banyak tradisi keagamaan, ragam etnis, bahasa, dan budaya lokal. Ragam Agama yang ada di Indonesia sangatlah banyak, bahkan dalam lingkup agama sendiri juga terdapat bermacam-macam aliran, golongan, sekte dan mazhab, hal ini menunjukkan bahwa bangsa Indonesia dihadapkan pada aneka ragam kenyataan yang plural. ${ }^{1}$ Kata plural merupakan asal kata dari pluralisme yang berarti banyak atau berbilang, sedangkan secara istilah plural merupakan ketulusan hati pada setiap manusia untuk menerima keanekaragaman yang ada. Oleh sebab itu, makna penting konsep pluralism yang memperoleh perhatian secara mendalam adalah hubungan sosial antarumat beragama, yang mana relasi tersebut senantiasa diwarnai dengan perbedaan bahkan konflik. ${ }^{2}$

Pluralisme agama merupakan tantangan khusus yang dihadapi setiap agamaagama dunia dewasa ini. Jika tidak dipahami secara benar dan arif, hal tersebut akan menimbulkan dampak negatif yang tidak hanya berupa konflik antarumat beragama saja, tetapi juga konflik sosial dan disintegrasi bangsa. Maka tidak bisa dipungkiri pluralisme di Indonesia masih menjadi bagian penting dalam berbagai diskusi bahkan menimbulkan pro-kontra di antara masyarakat. Dalam sejarahnya, tanah Nusantara merupakan tempat bernaung, keluar masuk dan bertemunya berbagai tradisi Timur dan Barat. Di dalamnya terdapat berbagai etnis dan terdapat pula bermacam-macam agama. Agama yang diakui di negeri ini di antaranya adalah Hindu, Buddha, Islam, Kristen (Katolik dan Protestan) serta Konghucu. Sejarah panjang relasi antarumat beragama senantiasa diwarnai oleh pasang surut antara damai dan konflik.

Pada masa tertentu, sejarah kehidupan antarumat beragama diwarnai oleh keharmonisan, kerukunan, dan terciptanya kehidupan yang damai. Penganut agama dari berbagai agama saling bertoleransi dan menghargai perbedaan yang ada. ${ }^{3}$ Dari konteks ini, menggali makna pendidikan dalam bingkai perbedaan menjadi penting untuk dipahami secara mendalam. Pendidikan memiliki peran

${ }^{1}$ Al Makin, Keragaman dan Perbedaan Budaya dan Agama dalam Lintas Sejarah Manusia (Yogyakarta: Suka Press, 2016), hal. 141.

${ }^{2}$ Ngainun Naim, Islam dan Pluralisme Agama (Yogyakarta: Aura Pustaka, 2014), hal. 6-7.

${ }^{3}$ Ibid., hal. 9. 
penting untuk menumbuhkan kesadaran manusia, agar tidak hanya dapat menerima keberadaan agama lain, tetapi juga mampu bekerja sama dengan mereka yang memiliki keyakinan lainnya, sehingga sebagai makhluk sosial kita dapat membangun dunia baru yang lebih bermakna dengan kultur yang beragam. ${ }^{4}$ Lebih-lebih kultur yang ada di Indonesia, pendidikan menjadi bagian yang sangat urgen dalam mengimplementasikan pendidikan karakter bangsa yang penuh nilai kemanusiaan tersebut.

Salah satu provinsi di Indonesia yang terkenal akan kearifan budaya lokal dan sosialnya adalah Daerah Istimewa Yogyakarta. Yogyakarta adalah sebuah provinsi dengan penduduk yang heterogen, mulai dari suku bangsa, agama, etnis maupun budayanya. Kemajemukan yang ada tidak membuat Yogyakarta menjadi kota yang terpecah-pecah dan penuh kekerasan. Hal itulah yang akhirnya menobatkan kota pendidikan ini sebagai "City of Tolerance". Maka tidak salah jika Yogyakarta memiliki slogan "Jogja, Berhati Nyaman", dalam artian masyarakat di dalamnya saling memiliki rasa kenyamanan dan saling merasa aman satu sama lain.

Namun pada momentum waktu yang lain, relasi ini justru diwarnai oleh lahirnya ketegangan, pertentangan, konflik, kekerasan dan berbagai sisi negatif lainnya. Sejak tahun 2010, Yogyakarta mulai marak dengan aksi-aksi intoleransi, tetapi yang sangat disayangkan dari sekian banyak jumlah kasus intoleransi dilakukan dengan tindak kekerasan. Hampir semua kasus tidak diproses secara komprehensif oleh aparat penegak hukum. ${ }^{5}$ Padahal seharusnya kasus demi kasus segera ditindaklanjuti sebagaimana mestinya agar tercipta kehidupan sosial yang harmonis dan sejahtera.

Dalam rentan tahun 2017 hingga 2019 terdapat beberapa kasus intoleransi di Yogyakarta, seperti kasus pembubaran acara bakti sosial gereja Katolik di Bantul, pelarangan sedekah laut di Srandakan, penyerangan diskusi Irshad Manji di LKiS, yang mana hampir semua aksi-aksi tersebut dilakukan oleh kelompok Islam

${ }^{4}$ Hujair AH Sanaky, Dinamika Perkembangan Pendidikan Islam di Indonesia (Yogyakarta: Kaukaba Dipantara, 2016), hal. 218.

${ }^{5}$ Lembaga Bantuan Hukum (LBH), "Perkembangan Kelompok Milisi Sipil, Kekerasan, danAncaman terhadap Perkembangan HAM di Yogyakarta," diakses dari www.lbhyogyakarta.org, pada tanggal 13 Agustus 2019 pukul 13.00 WIB. 
fundamentalis. ${ }^{6}$ Kasus-kasus tersebut tercatat belum tertangani secara serius oleh pemerintah, sehingga dikhawatirkan ada ketegangan yang lebih terasa di masyarakat jika hal tersebut tidak diatasi secara arif, cepat, dan tepat.

Selain itu, di awal tahun 2019 ini ditemukan kembali kasus intoleransi berupa penolakan warga nonmuslim bernama Slamet Jumiarto yang ingin bermukim di salah satu perkampungan di Kabupaten Bantul. Pada mulanya warga tidak merasa keberatan akan hal ini, tetapi salah satu aparat desa bersikeras menolak Slamet dan keluarganya untuk tinggal di pemukiman atas dasar aturan desa setempat. ${ }^{7}$ Adanya kasus tersebut menunjukkan minimnya pengetahuan kewarganegaraan dari warga setempat bahwa negara pada dasarnya telah melindungi hak kebebasan warganya untuk memeluk agama yang diyakini.

Jika dilihat dari rentetan di atas, hal tersebut dilatar belakangi dengan adanya kelompok-kelompok tertentu yang membawa nama agama ataupun aliran ke dalam ruang publik, sehingga mereka menganggap bahwa aksinya merupakan aksi kebenaran berdasarkan keyakinan agama versi mereka. Tentu hal ini menjadi keprihatinan kita bahwa masih banyak umat beragama belum memahami dan menyadari makna agama di dalam kehidupan mereka. Maka tidak mengherankan pada tahun 2014 Wahid Foundation menjadikan Yogyakarta menempati peringkat kedua sebagai kota paling intoleran setelah Kota Bandung. ${ }^{8}$ Menyikapi hal tersebut sebuah komunitas perempuan yang bernama "Srikandi Lintas Iman" hadir sebagai bentuk kepedulian perempuan-perempuan lintas agama di Daerah Istimewa Yogyakarta untuk duduk bersama, berbagi dan bertukar gagasan serta program untuk mengelola keberagaman agama, sosial dan budaya.

Komunitas ini menjadikan perempuan sebagai tokoh utama dalam mengawal keberagaman. Disisi lain juga karena perempuan merupakan sosok yang dianggap mampu merangkul banyak oknum, baik keluarga, teman, tetangga, atau masyarakat. Hal ini dengan harapan agar perempuan juga bisa menjadi

\footnotetext{
${ }^{6}$ Nindias Khalika, "Mengapa Insiden Intoleransi di Yogyakarta Terus Terjadi," diakses dari https://jogja.idntimes.com/newa/jogja/, pada tanggal 19 Juli 2019 pukul 13.00 WIB.

${ }^{7}$ Aturan Desa, "SK Nomor 03/POKGIAT/Krt?Plt/X//2015," n.d., n. Di dalam SK tersebut di jelaskan bahwa sebagai pendatang baru harus beragama Islam, sama dengan agama yang dianut oleh mayoritas penduduk.

${ }^{8} \mathrm{CNN}$ Indonesia, diakses dari https://www.cnnindonesia.com/nasional/2016080821144020-150068/, pada tanggal 5 Juli 2019 pukul 15.00 WIB.
} 
pemicu untuk mewujudkan perdamaian. ${ }^{9}$ Hal ini menunjukkan bahwa perempuan memiliki peran penting sama halnya dengan laki-laki dalam hal visi dan misinya sebagai agen penggerak perdamaian. Jika dilihat dari latar belakang komunitas ini, "Srikandi Lintas Iman" berasal dari berbagai organisasi perempuan keagamaan di wilayah Yogyakarta, seperti Fatayat (Nahdlatul Ulama), Nasyiatul Aisyiyah (Muhammadiyah), Wanita Katolik Indonesia dan Perempuan Konghucu Indonesia. Tidak hanya itu, ada pula yang dari perguruan tinggi keagamaan, seperti Sekolah Tinggi Hindu Dharma Klaten dan Universitas Kristen Duta Wacana, dan lainnya. ${ }^{10}$ Dari konteks ini, terdapat pendidikan multikultural yang menjadi dasar pemersatu perempuan-perempuan lintas agama pada komunitas ini.

Menjadi penting untuk ditelaah lebih lanjut bagaimana komunitas perempuan "Srikandi Lintas Iman" ini mampu menjadi sebuah gerakan dalam mengatasi berbagai persoalan intoleransi di Yogyakarta dan sekitarnya. Langkah penting untuk mengatasi berbagai persoalan intoleransi adalah membuka ruang dialog secara luas dan dikelola dengan baik, sehingga dengan itu mampu membuka wawasan dan pengetahuan untuk menyadarkan masyarakat. Dengan hal tersebut pemerintah atau kelompok yang berkecimpung di dunia itu turut andil dalam menyusun kebijakan dan mencari solusi bersama, khususnya di ruang pendidikan, agar warga sekolah mampu tumbuh cara berpikir secara moderat. Di sini pendidikan multikultural menjadi penting untuk ditanamkan kepada peserta didik agar tertanam kesadaran berpikir dan bersikap terhadap keanekaragaman yang ada.

Maka dari itu, di dalam artikel ini mencoba mengungkapkan bagaimana gerakan komunitas perempuan "Srikandi Lintas Iman" Yogyakarta jika ditelaah dalam konteks pendidikan Islam multikultural, bagaimana implikasi pendidikan Islam multikultural pada komunitas perempuan ini dalam mengelola keberagaman agama di Yogyakarta dan sekitarnya, serta apa faktor pendukung gerakan komunitas perempuan ini mampu bertahan serta berkontribusi bagi agama, bangsa, dan Negara Indonesia.

${ }^{9}$ Wawancara dengan MW Selaku Sekretaris Srikandi Pengawal Keberagaman", pada 4 Oktober 2018.

${ }^{10}$ DAAITV, “Srikandi Pengawal Keberagaman,” ditayangkan 20 Oktober 2018. 


\section{METODE PENELITIAN}

Penelitian ini menggunakan jenis penelitian kualitatif (field research), yakni peneliti terjun langsung ke objek yang diteliti untuk mengadakan pengamatan tentang suatu kejadian yang pasti. Penelitian ini bertujuan untuk memperoleh makna yang diperoleh dari fakta-fakta yang diteliti. Oleh karena itu, dalam pengumpulan data kualitatif harus dibuktikan dengan data yang pasti dan relevan. Dalam penelitian ini, peneliti merupakan instrumen kunci. Adapun teknik pengumpulan data menggunakan triangulasi sumber, analisis datanya bersifat induktif, dan hasil penelitian kualitatif lebih menekankan makna dari pada generalisasi. ${ }^{11}$

Penelitian ini menggunakan pendekatan fenomenologi yang dikemukakan oleh Alfred Schutz. Schutz memusatkan perhatian pada cara orang memahami kesadaran orang lain, tetapi ia hidup dalam aliran kesadaran diri sendiri. Pendekatan ini mendeskripsikan pemaknaan umum dari sejumlah individu terhadap berbagai pengalaman hidup terkait dengan konsep atau fenomena. Tujuan dari fenomenologi adalah untuk mereduksi berbagai pengalaman individu pada fenomena menjadi sebuah deskripsi tentang esensi universal. ${ }^{12}$ Maka di sini peneliti akan mempelajari secara mendalam tentang dinamika, fenomena dari interaksi sosial yang terjadi dalam komunitas perempuan "Srikandi Lintas Iman" sehingga hal tersebut dapat tergali nilai pendidikan Islam multikultural di dalamnya.

Dalam pelaksanaannya, peneliti menerapkan beberapa metode, yakni 1). Wawancara. Peneliti dalam hal ini mewawancarai beberapa orang yang terkait dan memungkinkan dapat memberikan informasi yang akurat, yakni ketua komunitas perempuan "Srikandi Lintas Iman" sebagai informan kunci, dan lima pengurus yang aktif dalam komunitas ini. 2). Observasi. Peneliti mengamati secara langsung ke lapangan dan ikut serta dalam kegiatan-kegiatan yang memungkinkan dapat diikuti agar peneliti memperoleh pemahaman yang mendalam terkait pendidikan Islam multikultural yang ada pada komunitas perempuan ini. 3). Dokumentasi. Data dokumentasi di sini dapat berupa catatan,

${ }^{11}$ Afifuddin, Metodologi Pendidikan Kualitatif (Bandung: Pustaka Setia, 2012), hal. 57-59.

${ }^{12}$ John W. Creswell, Qualitative Inquiry and Research Design, Terj. Ahmad Lintang Lazuardi (Yogyakarta: Pustaka Pelajar, 2015), hal. 105. 
transkip buku, surat kabar, gambar, video, film, rekaman atau karya-karya dari seseorang yang digunakan untuk memperjelas data yang dibutuhkan terkait keberadaan komunitas perempuan "Srikandi Lintas Iman” Yogyakarta.

Metode analisis data yang peneliti gunakan adalah analisis data kualitatif menurut Cresswell, dengan langkah-langkah analisis sebagai berikut, 1). Mengorganisasikan dan menyiapkan data yang akan dianalisis, 2). Membaca dan melihat seluruh data terkait komunitas perempuan ini, 3). Membuat koding seluruh data yang ada, 4). Menggunakan koding sebagai bahan untuk membuat deskripsi lebih lanjut, 5). Menghubungkan antar tema yang terkait dengan penelitian ini, dan 6). Memberi interpretasi dan makna tentang tema dalam penelitian. $^{13}$

\section{HASIL DAN PEMBAHASAN}

\section{A. Pendidikan Islam Multikultural}

Menurut R. Ibnu Ambarudin, pendidikan multikultural merupakan proses pengembangan sikap dan tata laku seseorang atau sekelompok orang dalam usaha mendewasakan manusia melalui upaya pengajaran, pelatihan, proses perbuatan dan cara-cara mendidik yang menghargai pluralitas dan heterogenitas secara humanistik. ${ }^{14}$ Pluralitas agama merupakan hal yang tidak bisa dipungkiri, karena Indonesia yang mewajibkan warganya menganut agama sewajarnya harus memberikan kenyamanan dan kasih sayang terhadap mereka yang berbeda agama dan keyakinan. Hal ini sebagaimana hadis Nabi, "Orang yang tidak berkasih sayang terhadap sesama, maka tidak diberi rahmat oleh Tuhannya." 15

Dari hadist tersebut, siapapun mereka, apapun ras dan agamanya, dan bagaimanapun sosial budayanya, manusia yang beragama harus terus memberikan kasih sayang dan perhatian baik kepada sesama. Maka dalam Islam, karakteristik pendidikan multikultural ini dapat dipahami menjadi

\footnotetext{
${ }^{13}$ Sugiyono, Metode Penelitian Kualitatif untuk Penelitian yang Bersifat: Eksploratif Interaktif dan Konstruktif (Bandung: Alfabeta, 2017), hal. 126-163.

${ }^{14} \mathrm{R}$. Ibnu Ambarudin, "Pendidikan Multikultural untuk Membangun Bangsa yang Nasionalis dan Religius," Jurnal Civic 13, no. 1 (2016): hal. 31-32.

${ }^{15}$ Al Syarif Ibn Muhammad Ibnu Kamal Al-Din Ibrahim, "Al-Bayān Wa Al-Ta'rīf Fī Asbāb Al-Wurūd" (Beirut: Maktabah Ilmiyah, 2007), hal. 240.
} 
tiga, yakni 1). Belajar hidup dalam perbedaan, 2). Terbuka dalam berpikir, dan 3). Mengaktualisasikan resolusi konflik.

Kita menyadari bahwa Negara Indonesia memiliki ratusan (bahkan ribuan) aneka ragam kebudayaan yang tersebar di seluruh pelosok masyarakat. Dengan keanekaragaman ini kita dapat mewujudkan masyarakat multikultural jika warganya dapat hidup berdampingan, toleran dan saling menghargai. Nilai budaya tersebut bukan hanya dijadikan sebagai wacana, tetapi harus menjadi dasar penilaian atau pedoman etika dan moral dalam bertindak yang benar dan pantas bagi setiap manusia Indonesia. Di titik ini, umat Islam terus berupaya dan mencari jalan untuk mengembangkan semua potensi secara yang efektif bagi kehidupan guna kesejahteraan dan kemakmuran individu dan komunitas. Namun demikian, evolusi kebudayaan seringkali menjelaskan secara nyata bahwa gerakan evolusioner yang telah direncanakan dan diupayakan sebaik mungkin tidak selalu sesuai dengan cita- cita sosial umat Islam. Dari segi substansinya, agama-agama mulai mengupayakan realisasi komunitas global universal dengan visi dan nasib bersama. ${ }^{16}$

Dalam implementasi pendidikan multikultural, lembaga pendidikan harus menanamkan kesadaran individu mengenai perbedaan dalam kehidupan yang majemuk ini. Suatu kenyataan yang plural membutuhkan kesadaran bahwa moralitas dan kebaikan dapat lahir dalam konstruk agamaagama lain. ${ }^{17}$ Berhasil atau tidaknya pendidikan multikultural itu dapat dilihat ketika pendidikan mampu membentuk sikap seseorang menjadi saling toleran, tidak berkonflik, tidak bermusuhan karena perbedaan suku, budaya, adat-istiadat, bahasa dan agama. ${ }^{18}$ Oleh karena itu, nilainilai yang harus diperhatikan dalam pendidikan multikultural antara lain: 1). Toleransi, 2). Keadilan, 3). Pluralisme, 4). Perdamaian, dan 5). Inklusif.

Maka dari itu, inti tujuan dari pendidikan multikultural dalam Islam adalah sebagai berikut:

${ }^{16}$ Zakiyuddin Baidhawi, Pendidikan Agama Berwawasan Multikultural (Jakarta: Erlangga, 2005), hal. 8.

${ }^{17}$ Choirul Mahfud, Pendidikan Multikultural (Yogyakarta: Pustaka Pelajar, 2010), hal. 217.

${ }^{18}$ Syamsul Ma'arif, Pendidikan Pluralisme di Indonesia (Yogyakarta: Logung Pustaka, 2005), hal. 95. 


\section{Ta'aruf}

Mengenal di sini bukan hanya sekedar mengenal oleh satu pihak tetapi oleh kedua belah pihak. Ta'aruf adalah inisiatif aktif dari beberapa pihak untuk saling mengenal dan tidak membiarkan satu sama lain. Dengan demikian, ta'aruf menjadikan sebuah perbedaan adalah rahmat, bukan laknat dan kebencian.

2. Istibaq

Istibaq di sini sering diistilahkan dengan makna saling berkompetisi satu sama lain. Dari adanya keberagaman kultur masyarakat, dengan segala potensinya sangat dimungkinkan untuk menambah pengetahuan dan keterampilan serta menjadi penunjang agar dapat melakukan hal yang bernilai positif untuk berkompetisi dengan baik.

\section{Hayatan Thayyibah}

Islam menempatkan pendidikan di tempat yang mulia. Dengan pendidikan, umat Islam bisa menjadi umat yang berkualitas. Di sini umat Islam harus memahami dan menyadari peran pendidikan multikultural yang didasarkan pada nilai-nilai ajaran Islam, sehingga kehidupan yang baik dan damai bisa dirasakan bersama-sama. ${ }^{19}$

\section{B. Gerakan Komunitas Perempuan "Srikandi Lintas Iman" dalam Bingkai Nilai Pendidikan Islam Multikultural}

Pendidikan Islam Multikultural merupakan pendidikan tentang keberagaman yang dilihat dari sudut pandang Islam. Sebagaimana Islam dalam sejarahnya telah memberikan suri tauladan tentang kehidupan toleransi beragama yang terjadi pada masa Nabi Muhammad SAW. Dengan pendidikan Islam multikultural, harapannya kerukunan dan perdamaian akan tercipta dengan harmonis, karena antara satu dengan yang lain saling menghargai dan menghormati. Tatanan kehidupan yang harmonis merupakan kehidupan yang diidam-idamkan setiap orang pada umumnya, baik itu laki-laki maupun perempuan. Dalam hal ini Islam memandang,

\footnotetext{
${ }^{19}$ Hamim Ilyas, Multikulturalisme dalam Islam (Memahami Prinsip, Nilai, dan Tujuan Multikulturalisme dalam Islam untuk Mencapai Kualitas Keterpilihan) (Yogyakarta: Idea Press, 2005), hal. 259-298.
} 
bahwa pendidikan multikutural menjadi sangat penting untuk dijadikan pedoman hidup di tengah ragamnya perbedaan.

Sebagai makhluk Tuhan yang memiliki sifat feminism, perempuan sering dianggap kurang berdaya dalam menjalankan tugas apapun, sehingga ia hanya bertugas di rumah, mengurusi anak dan keluarganya. Padahal Islam memiliki porsi yang sama dengan laki-laki dan telah memberikan solusi baik dalam ranah pendidikan, ekonomi dan sosial kulturnya. Mengingat perempuan adalah pendidik pertama bagi anakanaknya, maka perempuan mempunyai kewajiban untuk mengajarkan ajaran-ajaran yang ramah anak sesuai dengan ajaran Islam dan perkembangan zaman. Di samping itu, maraknya radikalisme yang terus berkembang baik di Indonesia, menimbulkan kekhawatiran tersendiri bagi bagi banyak orang, lebih-lebih kaum perempuan. Oleh karena itu, Islam memberikan peluang yang sama terhadap laki-laki dan perempuan dalam hal memperoleh pendidikan, aktif di bidang sosial, politik, dan seterusnya.

Komunitas perempuan "Srikandi Lintas Iman" merupakan satusatunya komunitas dari kalangan perempuan di Daerah Istimewa Yogyakarta yang anggotanya memiliki latar belakang berbeda, baik dari segi usia, suku, budaya dan agama. Sebagaimana telah diketahui bersama bahwa isu sosial yang mendapat sorotan masa dan media massa beberapa tahun terakhir ini adalah terkait konflik relasi antarumat beragama. Dari hal tersebut, sejumlah perempuan lintas keyakinan tergerakkan hatinya untuk berpartisipasi dalam menyemai nilai perdamian dan mengawal perbedaan yang ada.

Komunitas ini merupakan komunitas cair dan berbasis volunteer. Komunitas ini mengajak kaum perempuan untuk ikut andil dalam menyemaikan nilai-nilai perdamaian, karena hakikatnya perempuan mempunyai peran dan posisi yang penting dalam membina keberagaman. Partisipasi perempuan dalam komunitas ini diwujudkan dalam beberapa aktivitas-aktivitas berbasis lintas iman yang dikemas dalam berbagai bentuk kegiatan yang menarik, di antaranya adalah: 
1. Diskusi Lintas Iman

Dalam hal ini, diskusi memiliki peran aktif dalam membuka wawasan multikulturalisme, bahwa kedudukan manusia sebagai makhluk sosial tidak bisa lepas dengan yang namanya perbedaan. Oleh karena itu, kegiatan ini dibutuhkan dalam rangka melatih kesadaran dan keterbukaan pemikiran manusia sebagai umat beragama atas kebenaran sepihak, yang akhirnya menimbulkan pemikiran yang fanatik terhadap penganut agama lain. Hal ini sesuai dengan ajaran Islam, di mana diskusi dijadikan sebagai salah satu metode dalam penyampaian pendidikan dan upaya dalam penyelesaian suatu masalah.

Dalam diskusi lintas iman ini, komunitas ini selalu menyelenggarakan diskusi untuk umum. Bahkan di beberapa kesempatan, diskusi dihadiri oleh berbagai peserta dengan latar belakang agama seperti Islam, Kristen, Katolik, Hindu, Buddha dan Konghucu. $^{20}$ Kegiatan diskusi yang sering dilaksanakan oleh komunitas ini adalah hari libur nasional (atau hari Minggu). Hal ini karena mayoritas anggotanya berasal dari kalangan akademisi. Meskipun demikian, setiap kegiatan diskusi selalu meriah dan banyak peserta yang hadir.

Berdasarkan pengamatan peneliti, kegiatan ini memiliki tujuan tidak hanya untuk berbagi ilmu pengetahuan dan pengalaman, tetapi juga menjadi ajang saling mengenal satu sama lain, baik antar individu maupun terkait wawasan keagamaan yang berbeda-beda. Komunitas ini mengajak anggotanya untuk duduk bersama dalam rangka mengenal lebih dekat tokoh dan ajaran yang berkaitan dengan lintas keyakinan. Dengan mengenal tata hidup keagamaan yang berbeda, maka jalinan persaudaraan pada komunitas ini terlihat sangat rukun dan damai.

${ }^{20}$ Wawancara dengan SA selaku Anggota Srikandi Lintas, pada 26 Juli 2019. 
2. Ziarah Lintas Iman

Ziarah Lintas Iman merupakan kegiatan rutin yang dilakukan oleh komunitas "Srikandi Lintas Iman" untuk mengunjungi tempattempat ibadah umat beragama. Ziarah lintas iman berfungsi sebagai sarana untuk mempertebal keimanan dan rasa toleransi. Tempat yang dikunjungi adalah rumah-rumah ibadah dan tempat suci. Seperti halnya masjid, makam wali, gua Maria, dan tempat-tempat yang dianggap suci oleh umat beragama, seperti Candi Borobudur dan ritus keagamaan lainnya. ${ }^{21}$

Ziarah lintas iman pada komunitas ini diadakan dalam rangka membina pengetahuan tentang keberagaman dan kesadaran pentingnya menerima perbedaan. Sebagaimana Islam juga menganjurkan untuk saling menyayangi terhadap sesama manusia, salah satu upayanya yakni dengan menjalin hubungan yang baik antar sesama. Kegiatan ini dilaksanakan setiap tahun sekali dan peserta ziarah hanya diperuntukkan untuk anggota komunitas "Srikandi Lintas Iman" saja. Kegiatan ini dilaksanakan untuk mengedukasi para perempuan anngota lintas iman untuk membuka wawasan keagamaan melalui pengenalan tempat, simbol, tata cara peribadatan umat lain beserta nilai filosofi di dalamnya. ${ }^{22}$

Jika kegiatan ini dikaitkan dalam konteks pendidikan Islam multikultural, tentu hal tersebut memiliki karakteristik yang sama, di antaranya: 1). Belajar hidup dalam perbedaan, dan 2). Terbuka dalam berpikir. Setiap manusia tidak terlepas dari perbedaan dan harus berinteraksi sosial dalam setiap perbedaan tersebut sehari-hari. Sehingga dengan adanya kegiatan ziarah lintas iman ini mampu memberikan pemahaman pendidikan yang menyeluruh terhadap semua aspek kehidupan untuk mewujudkan keseimbangan kehidupan dunia dan akhirat. Begitu juga saat mengunjungi tempat-tempat ibadah, mereka mendapatkan banyak pengetahuan yang disampaikan

\footnotetext{
${ }^{21}$ Wawancara dengan MH selaku Koordinator Divisi Pemberdayaan Srikandi Lintas Iman, pada 1 Agustus 2019.

${ }^{22}$ Wawancara dengan NK selaku Anggota Srikandi Lintas Iman, pada 11 Agustus 2019.
} 
oleh pihak terkait. Jadi, mereka selain berziarah juga belajar memahami sejarah dan nilai-nilai kehidupan.

3. Pelatihan Resolusi Konflik

Pelatihan resolusi konflik pada komunitas ini dilaksanakan dengan bekerja sama dengan lembaga-lembaga lain, seperti Pusat Studi Pengembangan Perdamaian Universitas Duta Wacana Yogyakarta, dan lembaga-lembaga lain yang terkait. Tujuan dari adanya kegiatan ini adalah agar para perempuan-perempuan di komunitas tersebut mampu mengatasi konflik dan bisa mengajarkan kembali kepada orang-orang yang ada disekitarnya.

Pelaksanaan pelatihan ini dilakukan selama tiga hari berturutturut. Acara ini diperuntukkan kepada anggota "Srikandi Lintas Iman" dan pihak-pihak yang bekerjasama. Pelatihan resolusi konflik ini disajikan dengan materi-materi menarik, seperti diselingi permainan edukasi tentang konflik dan perdamaian. Intinya dalam pelatihan tersebut, mereka diajarkan tentang mengenal satu sama lain, belajar mengatasi konflik berdasarkan sumber dan akibatnya. ${ }^{23}$ Adapun upaya-upaya yang harus dilakukan dari hasil pelatihan resolusi konflik tersebut antara lain:

a. Koersi

Koersi diartikan sebagai penyelesaian konflik dengan menekan atau memaksa salah satu pihak yang berseteru. Biasanya yang melakukan penekanan tersebut adalah pihak yang memiliki kedudukan dan level pendidikan yang lebih tinggi dari lawannya.

b. Arbitrasi

Pada tahap ini, perlu ada pihak ketiga, yakni sebagai penengah yang memutuskan persoalan kedua belah pihak tersebut. Pihak ketiga tersebut biasanya adalah orang yang memiliki kekuasaan dan dianggap adil oleh masyarakat.

\footnotetext{
${ }^{23}$ Wawancara dengan $\mathrm{MH}$, op. cit.,.
} 
c. Mediasi

Pada tahap ini, pihak ketiga berperan menyediakan fasilitas saja dan tidak berhak memberi keputusan. Karena yang berhak hanya kedua belah pihak yang berkonflik. Pada tahap ini, jika konflik belum bisa terselesaikan, maka mediator tidak bisa melanjutkan aksinya. Artinya konflik itu tidak bisa diselesaikan.

d. Negosiasi

Negosiasi merupakan proses di mana kedua belah pihak mencapai kesepakatan bersama. Tahap ini merupakan upaya penyelesaian konflik yang paling ideal, karena negosiasi memberikan keuntungaan pada kedua belah pihak yang berkonflik. $^{24}$

\section{Implikasi Pendidikan Islam Multikultural pada Komunitas Perempuan "Srikandi Lintas Iman" dalam Mengelola Keberagaman}

Pendidikan Islam multikultural merupakan upaya umat Islam dalam memperoleh kehidupan yang rukun dan damai serta santun dalam menyikapi perbedaan dalam segala hal. Hal ini menunjukkan bahwa Islam mengakui dan menghargai adanya pluralitas. Sebagai suatu keniscayaan bahwa keberagaman adalah sunnatullah yang patut untuk disyukuri. Melalui beberapa program yang telah dijalankan oleh komunitas perempuan "Srikandi Lintas Iman", di sini akan dijelaskan implikasi dari praktik pendidikan Islam multikultural terhadapnya dalam mengelola keberagaman di Yogyakarta dan sekitarnya, yakni antara lain:

1. Nilai Inklusif

Diskusi yang diikuti oleh perempuan di komunitas ini memberikan wawasan baru bagi anggotanya untuk saling terbuka satu sama lain. Mereka bisa hidup bersandingan dengan yang berbeda. Artinya komunitas ini memberikan kenyamanan bagi anggotanya dalam menjalin interaksi dan relasi sesuai dengan keyakinannya masing-masing. 
Di dalam ajaran agama sendiri, Islam Islam pada dasarnya mengajarkan bahwa tidak ada paksaan dalam memeluk agama, bahkan Islam dengan prinsip cinta kasihnya itu berlaku terhadap semua umat manusia, termasuk yang tidak seiman dengan pemeluk Islam. Dengan adanya penyadaran tersebut, umat manusia seharusnya memahami pentingnya nilai inklusifitas dalam kehidupan. Hal tersebut sesuai dengan firman Allah Q.S. Al-Anbiyā' ayat 107.

2. Nilai Toleransi

Menurut salah satu anggota komunitas ini, sejak ia masuk di komunitas "Srikandi Lintas Iman", ia telah belajar tentang banyak hal, seperti belajar bersosialisasi dengan yang mereka berbeda keyakinan dan belajar dalam menyikapi perbedaan, sehingga hubungan antar-anggota komunitas ini sangat dekat seperti halnya keluarga sendiri. ${ }^{25}$ Nilai toleransi ini terus diterapkan secara baik pada komunitas ini. Oleh sebab itu, diskusi menjadi sangat penting sebagai metode untuk mengkomunikasikan hal-hal yang perlu ditinjau ulang dalam rangka menyampaikan pesan pendidikan, seperti halnya pendidikan Islam multikultural.

3. Nilai Keadilan

Dalam penyelesaian suatu konflik diperlukan keadilan untuk menjembatani konfik yang terjadi, seperti halnya mediator yang tidak boleh memihak salah satu dari dua pihak yang berkonflik. Berdasarkan penuturan dari salah satu anggota komunitas perempuan ini, konflik pada hakikatnya bisa terjadi kapanpun dan di manapun, tetapi adanya upaya untuk menghindari konflik akan memudahkan dalam menghadapinya. Hal ini berbeda ketika suatu konflik dibiarkan begitu saja tanpa ada penanganan serius. Maka dari itu, nilai keadilan perlu ditumbuhkan sejak dini, agar manusia lebih bijak dalam menghadapi setiap konflik.

\footnotetext{
${ }^{25}$ Wawancara dengan SA, op. cit..,
} 
4. Nilai Perdamaian

Konflik yang terselesaikan dengan baik, tentu akan menumbuhkan kedamaian bagi pihak yang sebelumnya berseteru. Hal ini sudah dibuktikan oleh salah satu anggota komunitas perempuan "Srikandi Lintas Iman" ini, ia menceritakan tentang salah satu anggota Srikandi Lintas Iman yang turut menggugat atas kasus pemotongan Salib yang terjadi di salah satu pemakaman muslim di Yogyakarta. Dalam hal ini, ia tidak serta merta langsung bertindak ke ranah hukum, tetapi membantu mencari akar masalah yang sebenarnya. Setelah dirasa cukup, ia bersama teman-temannya menyelesaikan secara baik kasus tersebut dengan melibatkan berbagai pihak. ${ }^{26}$ Oleh karena itu, sebagai umat beragama (khususnya umat Islam), patut menjadi teladan dalam mewujudkan perdamaian di tengah kehidupan sosial yang beragam di tanah Indonesia.

\section{Faktor Pendukung Gerakan Komunitas Perempuan "Srikandi Lintas Iman" Yogyakarta}

Dalam rangka mewujudkan pendidikan Islam multikultural di komunitas perempuan "Srikandi Lintas Iman", para pengurus dan anggota komunitas ini tidak luput dari segala hal yang mendukung terlaksananya program-program yang akan, sedang, dan telah dijalankan oleh komunitas ini. Adapun faktor-faktor pendukung dalam gerakan komunitas perempuan ini adalah:

1. Solid dalam menjalankan visi dan misi bersama

Hal ini diwujudkan saat kegiatan open recrutment anggota baru "Srikandi Lintas Iman" dengan mengikuti beberapa matrikulasi yang memang tujuannya untuk menyamakan visi misi antar-anggota. Melalui matrikulasi tersebut, anggota komunitas perempuan ini dibekali pengetahuan tentang cara menyikapi perbedaan-perbedaan yang ada pada masing-masing agama. Dari kegiatan tersebut semakin memperkuat mereka untuk bekerja sama dalam menjalankan visi misi yang ada pada komunitas tersebut. Berawal dari semangat para 
perempuan ini, kegiatan-kegiatan lintas iman dapat direalisasikan dengan baik dan dapat berjalan dengan lancar.

2. Pemimpin selalu aktif dalam mengarahkan para anggotanya

Program yang terdapat pada komunitas perempuan ini diselenggarakan dalam rangka upaya dalam mengembangkan potensi para perempuan lintas iman dalam merespons isu-isu yang beredar di Yogyakarta dan sekitarnya, khususnya dalam kasus terkait perempuan dan anak. Oleh karena itu, ketua komunitas ini sering mengadakan arahan dan evaluasi bersama terkait program-program yang perlu dibentuk. Hal ini sangat penting demi eksistensinya gerakan sosial keagamaan ini.

3. Para anggota berasal dari berbagai latar belakang yang berbeda

Anggota komunitas perempuan "Srikandi Lintas Iman" hadir dari berbagai kalangan, seperti mahasiswa, dosen, Lembaga Swadaya Masyarakat (LSM), organisasi masyarakat, dan lembaga keagamaan. Dengan banyak anggota yang berbeda tersebut memberikan implikasi tersendiri, salah satunya komunitas perempuan ini memiliki relasi dan jaringan yang luas, sehingga dengan itu memudahkan dalam penyelenggaraan berbagai kegiatan.

4. Sistem kekeluargaan antar anggota masih terjaga baik

Interaksi positif antar-anggota menjadi faktor terselenggaranya kehidupan yang harmonis. Hal ini ditunjukkan saat komunitas perempuan ini bercengkerama, berdiskusi, saling menghargai bahkan saling bertukar informasi dan ilmu pengetahuan. Selain itu, kepedulian komunitas ini ditunjukkan dengan adanya kunjungan terhadap para korban dari beberapa kasus intoleransi di Yogyakarta, seperti kasus penyerangan jemaat gereja Santa Lidwina di Sleman Yogyakarta, dan seterusnya. ${ }^{27}$

Sikap toleransi pada komunitas ini masih dipertahankan dengan baik dan hal ini menjadi dasar kepribadian setiap anggota komunitas dalam menyikapi berbagai perbedaan baik dalam hal muamalah

\footnotetext{
${ }^{27}$ Wawancara dengan WSAR selaku Ketua Srikandi Lintas Iman, pada 19 November 2018.
} 
ataupun dalam menjalankan akidah mereka masing-masing. Oleh karena itu, sebagai umat beragama, khususnya umat Islam, cara pandang negatif terhadap mereka yang berbeda perlu dirubah. Cara pandang positif dengan melihat yang berbeda adalah keniscayaan merupakan bagian penting agar menyadari bahwa nilai kekeluargaan dan kemanusiaan perlu terus dijunjung tinggi sebagai bagian dari inti ajaran agama.

\section{KESIMPULAN}

Sebagai "City of Tolerance", masyarakat Yogyakarta semestinya saling memiliki rasa kenyamanan dan saling merasa aman satu sama lain. Sebagai kota pendidikan, semestinya warga masyarakat yang tinggal di Yogyakarta terus menjunjung tinggi nilai-nilai pendidikan dan kemanusiaan. Tetapi beberapa tahun terakhir, banyak kasus intoleransi terjadi di Yogyakarta yang membuat banyak orang berpikir ulang bagaimana hal tersebut bisa terjadi. Maka di sini komunitas perempuan "Srikandi Lintas Iman" hadir duduk bersama mencari solusi dalam rangka untuk mengelola keberagaman agama, sosial dan budaya yang ada.

Komunitas perempuan ini telah melakukan berbagai langkah penting untuk mengatasi berbagai persoalan intoleransi, salah satunya membuka ruang dialog. Dengan itu, mampu membuka wawasan dalam menyadarkan masyarakat secara luas. Maka implikasi dari hal tersebut, tentu lembaga formal pemerintahan dan komunitas terkait harus turut andil dalam mencari solusi bersama, khususnya dalam kebijakan di ruang pendidikan. Dari banyaknya kegiatan yang telah dilakukan oleh komunitas perempuan "Srikandi Lintas Iman" ini, sangat penting dipahami bahwa dibalik itu semua terdapat nilai-nilai pendidikan multikultural sehingga masyarakat umum (khususnya perempuan) mampu tertanam kesadaran berpikir dan bersikap terhadap keanekaragaman yang ada. Hal tersebut sebagai dasar ajaran agama yang harus tertanam dalam diri dan terus dijunjung tinggi dalam setiap langkah kehidupan manusia. 
Vol. 1, No. 4, (Oktober 2019): 425-444

\section{DAFTAR PUSTAKA}

Afifuddin. 2012. Metodologi Pendidikan Kualitatif. Bandung: Pustaka Setia.

Ambarudin, R. Ibnu. "Pendidikan Multikultural untuk Membangun Bangsa yang Nasionalis dan Religius." Jurnal Civic 13, no. 1 (2016).

Aturan Desa. “SK Nomor 03/POKGIAT/Krt?Plt/X//2015,”.

Baidhawi, Zakiyuddin. 2005. Pendidikan Agama Berwawasan Multikultural. Jakarta: Erlangga.

CNN Indonesia. https://www.cnnindonesia.com/nasional/20160808211440-20150068/, diakses pada 5 Juli 2019.

Creswell, John W. 2015. Qualitative Inquiry and Research Design. Diedit oleh Terj. Ahmad Lintang Lazuardi. Yogyakarta: Pustaka Pelajar.

DAAI TV. "Srikandi Pengawal Keberagaman," ditayangkan pada 20 Oktober 2018.

Ibrahim, Al Syarif Ibn Muhammad Ibnu Kamal Al-Din. 2007. "Al-Bayān Wa AlTa'rīf Fī Asbāb Al-Wurūd." Beirut: Maktabah Ilmiyah.

Ilyas, Hamim. 2005. Multikulturalisme dalam Islam (Memahami Prinsip, Nilai, dan Tujuan Multikulturalisme dalam Islam untuk Mencapai Kualitas Keterpilihan). Yogyakarta: Idea Press.

Khalika, Nindias. "Mengapa Insiden Intoleransi di Yogyakarta Terus Terjdi." https://jogja.idntimes.com/newa/jogja/, diakses pada 19 Juli 2019.

Lembaga Bantuan Hukum (LBH). "Perkembangan Kelompok Milisi Sipil, Kekerasan, dan Ancaman terhadap Perkembangan HAM di Yogyakarta." www.lbhyogyakarta.org/author/adminlbh, diakses pada 13 Agustus 2019.

Ma'arif, Syamsul. 2005. Pendidikan Pluralisme di Indonesia. Yogyakarta: Logung Pustaka.

Mahfud, Choirul. 2010. Pendidikan Multikultural. Yogyakarta: Pustaka Pelajar.

Makin, Al. 2016. Keragaman dan Perbedaan Budaya dan Agama dalam Lintas Sejarah Manusia. Yogyakarta: Suka Press.

Naim, Ngainun. 2014. Islam dan Pluralisme Agama. Yogyakarta: Aura Pustaka.

Observasi. "Kegiatan Pelatihan Resolusi Konflik.” Kabupaten Sleman, pada 18 Januari 2018. 
Sanaky, Hujair AH. 2016. Dinamika Perkembangan Pendidikan Islam di Indonesia. Yogyakarta: Kaukaba Dipantara.

Sugiyono. 2017. Metode Penelitian Kualitatif untuk Penelitian yang Bersifat: Eksploratif Interaktif dan Konstruktif. Bandung: Alfabeta.

"Wawancara dengan MH selaku Koordinator Divisi Pemberdayaan Srikandi Lintas Iman", pada 1 Agustus 2019.

"Wawancara dengan MW Selaku Sekretaris Srikandi Pengawal Keberagaman", pada 4 Oktober 2018.

"Wawancara dengan NK selaku Anggota Srikandi Lintas Iman", pada NK 11 Agustus 2019.

"Wawancara dengan SA selaku Anggota Srikandi Lintas", pada 26 Juli 2019.

"Wawancara dengan WSAR selaku Ketua Srikandi Lintas Iman", pada 19 November 2018. 